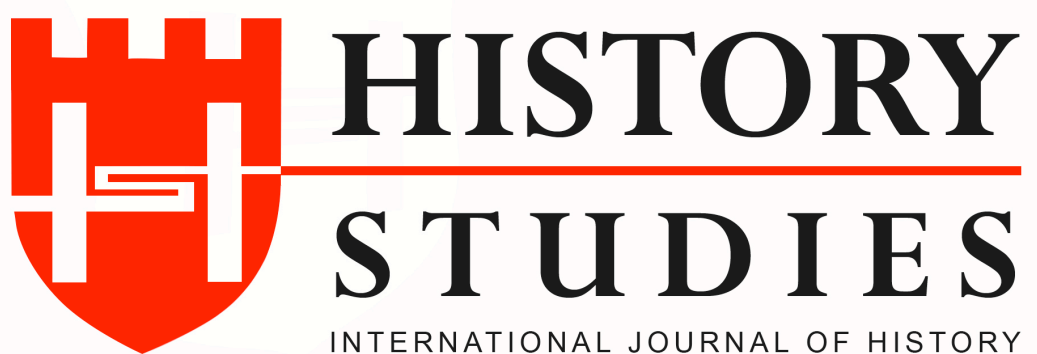

ISSN: 13094173 (Online) 1309 - 4688 (Print)

Volume 11 Issue 4, August 2019

DOI Number: 10.9737/hist.2019.765

Araştırma Makalesi

Makalenin Geliş Tarihi: 03.05.2019 Kabul Tarihi: 03.08.2019

Atıf Künyesi: Sabri Özçakır - Salih Başkutlu, "The Corps of Rum Scouts of Istanbul According to Ottoman Archival Documents in the Armistice Period (1918-1922)", History Studies, 11/4, Ağustos 2019, s. 1299-1311.

\title{
THE CORPS OF RUM SCOUTS OF ISTANBUL ACCORDING TO OTTOMAN ARCHIVAL DOCUMENTS IN THE ARMISTICE PERIOD (1918-1922)
}

\author{
Osmanlı Arşiv Belgelerine Göre Mütareke Dönemi’nde İstanbul Rum İzci Teşkilatı \\ (1918-1922)
}

\author{
Sabri ÖZÇAKIR - Salih BAŞKUTLU \\ ORCID No: 0000-0002-2179-2372 / 0000-0003-1676-6505 \\ Bolu Abant İzzet Baysal Üniversitesi - Munzur Üniversitesi
}

\begin{abstract}
The Corps of Rum Scouts of Istanbul was the most active and well-organized scouting organization in the Ottoman Empire during the Armistice period (1918-1922). In a short while this organization became quite popular among local Rum community. The Armistice years created a suitable miliue for the spreading of Rum scouting groups owing to the Ottoman's lack of authority over Rum community. This article intends to evaluate how Rum boy scout movement played such an important role in the promotion of Greek national identity among Rum population and how scouting activities aroused national awakening against Ottoman Empire. The Rum community living in the Ottoman territory produced strong tension through scouting organizations against the Ottoman authority. In conclusion, following the defeat of Greece in 1922, the Megali Idea ended with a national disaster for Greece and Rum community leading to a real national crisis and collective trauma. Then this organization completely disappeared from Istanbul and Asia Minor.
\end{abstract}

Keywords: The Corps of Rum Scouts of Istanbul, Megali Idea, Ottoman Greeks (Rums), Armistice period, Greek national consciousness.

Öz: İstanbul Rum İzci Teşkilatı, Mütareke döneminde (1918-1922) Osmanlı İmparatorluğu'nda bulunan en aktif ve en iyi organize edilmiş izcilik örgütüydü. Bu teşkilat, kısa bir süre içinde yerel Rum topluluğu arasında oldukça popüler oldu. Mütareke yılları, Osmanlı'nın Rum toplumu üzerindeki otorite eksikliğinden dolayı Rum izci gruplarının yaygınlaşması için uygun bir ortam yarattı. Bu makale Rum izci hareketinin Rum nüfusu içinde Yunan ulusal kimliğinin desteklenmesinde nasıl bu kadar önemli bir rol oynadığını ve izcilik faaliyetlerinin Osmanlı İmparatorluğu'na karşı ulusal uyanışı nasıl desteklediğini değerlendirmeyi amaçlamaktadır. Osmanlı topraklarında yaşayan Rum topluluğu, izcilik örgütleri aracılığıyla Osmanlı otoritesine karşı güçlü bir gerilim yarattı. Sonuç olarak, Megali Idea Yunanistan'1n 1922'deki yenilgisini takiben Yunanistan ve Rum toplumu için ulusal bir felaketle sonuçlanarak gerçek bir ulusal krize ve toplu travmaya yol açtı. Ardından bu teşkilat İstanbul ve Anadolu'dan tamamen kayboldu.

Anahtar Kelimeler: İstanbul Rum İzci Teşkilatı, Megali İdea, Osmanlı Rumları, Mütareke Dönemi, Yunan Ulus Bilinci. 


\section{Introduction}

During the first quarter of twentieth century, the boy scout movement, which was founded by Baden Powell in Britain, became widespread among the Muslim (Turks) and non-Muslim (Greek, Armenian, Jewish) groups of the Ottoman Empire. The Ottoman Boy Scout movement was soon influenced by the spread of scouting organizations in other countries. During and after II. Constitutional Period (1908-1918), the Ottoman boy scout organizations founded by Muslim and non-Muslim groups have made a massive effort to educate and mobilize younger generations to become disciplined, obedient, physically strong, self-sufficient, and civilized citizens of the future. ${ }^{1}$ Under the socio-political effects of nationalist ideologies, from the second half of the nineteenth century, children and youth were perceived as mini-adults and potential candidates of military service, in brief, ' the future of the nation'. ${ }^{2}$

During the Armistice period, which started at the end of the World War I and proved to be a major turning point of Ottoman-Turkish history, Ottoman minorities mainly Armenians and Rums, foreigners, and the Entente Powers attracted significant attention to scouting, particularly in Istanbul. The Boy Scout organizations and youth movements of Greek, Armenian, British, Italian, Russian and American communities were established in Istanbul and several parts of the Asia Minor for political and militaristic purposes. Although the OttomanTurkish Boy Scout movement continued performing its main functions and activities, it partially appeared to be non-progressive and keep from looking too militaristic because of the political and socio-economic conditions of the Armistice years. ${ }^{3}$

Additionally, the Muslim and non-Muslim elements of Ottoman society came together under the umbrella of different associations. For example, the prominent figures of these various groups, including Ottoman army officers, merchants, bureaucrats, Levantines and Europeans, met in sport clubs and crossed the borders of language, religion and race. ${ }^{4}$ The International Boy Scout Council of Constantinople was an example of this harmony between various groups. It was consisted of the scout groups of different nations living in Istanbul. Under the leadership of British Colonel Maxwell, there were a total of 3145 scouts, which included Turkish, Greek, Armenian, Jewish, British, American, Russian and Italian scout troops representing in this council. The organization of these scout groups basically was organized in schools clubs, sport associations, and orphanages. ${ }^{5}$ Despite this council aimed at serving Boy Scout movement, gathering different scout groups together, and strengthening the collaboration between them, it was unable to accomplish this. Additionally, it slightly enhanced the separation among these groups of people. The basic criticism against the International Boy Scout Council of Constantinople was that there was not enough international scouting and sport activities organized. ${ }^{6}$

\footnotetext{
${ }^{1}$ For more details on this alternative see Zafer Toprak, 'II. Meşrutiyet Dönemi'nde paramiliter gençlik örgütleri', in Tanzimat'tan Cumhuriyet'e Türkiye Ansiklopedisi, Vol. 2, 1985, p. 531-536.

${ }^{2}$ Nazan Madsukyan, "Agents or Pawns? Nationalism and Ottoman children during the Great War", Journal of the Ottoman and Turkish Studies Association, 3(1), 2016, p. 139-164.

${ }^{3}$ For details on the scouting activities of various elements of Ottoman society see Zafer Toprak, "Meşrutiyet ve mütareke yıllarında Türkiye'de izcilik", Toplumsal Tarih, 52, April 1998, p. 13-20.

${ }^{4}$ François Georgeon and ve Dumont (eds), Osmanlı İmparatorluğu'nda Yaşamak, İletişim Yayınları, İstanbul 2000, p. 19-21.

${ }_{5}^{5}$ Anna Maria Aslanoğlu, Staying away from politics, not foreseeing militarism: The case of Corps of Greek Scouts in Armistice Istanbul, 1918-1923, (Boğaziçi University, Unpublished master's thesis), Istanbul, 2010, p. 93-94.

${ }^{6}$ Zafer Toprak, "II. Meşrutiyet’ten Mütareke yıllarına: Türkiye'de izciliğin ilk evresi”, Tombak, 24, February 1999, p. 19-27.
} 
The Corps of Rum Scouts of Istanbul (hereafter the CRSI) was the most active and wellorganized scouting organization in Istanbul during the Armistice years. Even though this organization had a short period of experience, it attracted Istanbul Rums, who were eager to join and participate in scouting. This interest to scouting took attention of the nationalist Rums. Venizelism, as a popular and dominant ideology among Rums, was aimed to establish a Great Greece in Ottoman lands where the Rums live. Additionally, Venizelism potentially created suitable conditions for the development of Rum Scouting Organization in Istanbul and Asia Minor. ${ }^{7}$ The scouting culture discovered by the British political elites initiated a new interest in re-discovery of the Greek antiquity and its civilization. Scouting became a part of the chain that transferred a 'culture' and 'civilization' mission to the East. This explains why the scouting and the scouting organizations were so easily adopted by the Greek political elites and why the political elites cooperated with the 'scout press'. The discipline and dedication of the Greek scouts in the fronts of Balkan Wars against Ottoman Empire and also Bulgaria proved that this movement had to be maintained for the common good of the Nation. The Greek scouts performed rear-guard support activities, working as couriers, nurses and first aiders carrying the wounded, contributing to correspondence, and training new medical staff during the Balkan Wars. ${ }^{8}$

Although, scouting has existed as a device to mobilize and train Rums living in Ottoman territory since the pre-World War I years, most of the Ottoman archival documents of Rum scouts belongs to the Armistice period. These documents have relatively stable characteristics. ${ }^{9}$ During the phase of the construction and development of Rum Boy Scout movement, the most inspiring period was the Armistice period owing to the Ottoman's lack of authority and influence over the Rum population. Furthermore, by looking through the primary sources, mainly Ottoman archival documents, it was intended to make contribution to Ottoman and Greek history writing and the process of gaining national consciousness of Rum Orthodox community.

Significantly, from the very beginning, the Rum scouting had been presented as a voluntary and non-paramilitary organization and also envisioned as an ethnic and a patriotic association. Rum Boy Scout movement was considered as a challenge against central authority, Ottomans and seemed to be heralded of incipient Greek national identity among Ottoman Rums.

In recent years, historical researches have examined Rum-Ottoman relations from political and military perspectives; however, these researches rarely are interested in the roles of body culture and Boy Scout movement of Ottoman Rums in the Ottoman Empire. ${ }^{10}$ Therefore, this article ultimately intends to serve as a contribution to history field by examining the Rum scouting activities. In focusing on the experience of the Istanbul Rum Scouting Organization will be helpful for the understanding the overall aim of these activities. In this context, the purpose of this study is to evaluate how the Rum Boy Scout movement played such an important role in the promotion and propagation of Greek national identity among Rum population, and how scouting activities aroused national awakening against Ottoman Empire and increased the military strength of Rums in the Ottoman territory during the Armistice period.

\footnotetext{
${ }^{7}$ Aslanoğlu, op. cit., p. 12-13.

${ }^{8}$ Ibid., p. 70-75.

${ }^{9}$ Maksudyan, op. cit., p. 162.

${ }^{10}$ Here it should be mentioned that there is a noteworthy study of Anna Maria Aslanoğlu (see footnote 5) which mainly focused on Greek main sources such as the official gazette of the Corps of Greek Scouts of Constantinople, O Prospokos (The Scout), and archival material from the Corps of Greek Scouts in Greece.
} 


\section{The activities of the corps of Rum scouts in Istanbul}

With the signing of the Mondros Armistice (30 October 1918) after the World War I, occupations of the Entente Powers spread throughout Asia Minor and this political climate initiated a new period of scouting activities in the Ottoman Empire. Any kind of military or civilian organizations were forbidden by the Entente Powers since they contradicted their own interest. In this regard, Ottoman-Turkish Boy Scout movement cannot be isolated from this environment and there was no scouting organization except for a few in-school scouting programs. However, it is not possible to say that the non-muslim Ottoman population was exposed to the same sanction in this process. Despite the prosecution and warning decisions of the Ottoman administration, there was significant progress in the actions of Rum and also Armenian youth organizations. In other words, the organizations of the non-Muslim communities became more visible after World War I and Rum scouting organization acted as a crucial element in shaping nationalist and militarized socialization of Ottoman Rums. ${ }^{11}$

After the signing of the Mondros Armistice, the actions of the Ottoman Rums with the support of Greece proved that both sides acted in unison around the idea of "Megali Idea". Greek Prime Minister Venizelos seemed to willing to pursue the Megali Idea project in order to gain Ottoman Rums' support. The following were among the main objectives of Greece's government in Ottoman Empire during this period: establishing scout organizations in Istanbul and Asia Minor and training Rum scouts in order to reach the aims of Greece. ${ }^{12}$ On the other hand, scouting in Greece, first established in 1910 by a Greek gymnast, Athanasios Lefkatidis, with a great inspiration of the British Boy Scouts, and, during Venizelos' period, this youth movement flourished in particular owing to Venizelos' great interest in and support to the scouts. Moreover, the relation between scouting and state was quite intimate in his period. ${ }^{13}$ In fact, during the independence movement, physical exercises were practiced particularly by paramilitary groups in order to maintain body power. In the modern Greece, there has been a strong relationship between physical exercise and politics in Greek ideology. ${ }^{14}$

Although the Greek national movement against the Ottomans led to the establishment of the independent Greek state in 1830, this new state was completely formed different from other emerging European nation states. Because a majority of Greek population still remained under the Ottoman rule and an important and large part of this population also lived in the Ottoman cities, mostly in Istanbul, Izmir (Smyrna) and Selanik (Salonica). ${ }^{15}$ Furthermore, the liberation from Ottoman rule also allowed Greece to create a suitable environment in which Greek body culture or physical exercise can be developed and spread more easily, similar in some respects to other European nation-states. ${ }^{16}$ During the same period, physical exercise was linked with Greek national history and supported the experience of mass mobilization to the homeland. Moreover, by means of activities of militia soldiers (armatoloi) and bandits (klephts) against

\footnotetext{
${ }^{11}$ Madsukyan, op. cit., p. 141.

${ }^{12}$ Hülya Toker, Mütareke Döneminde Istanbul Rumları, Genelkurmay ATESE ve Denetleme Başkanlığı Yayınları, Ankara 2006, p. 51-55.

${ }^{13}$ Aslanoğlu, op. cit., p. 45; Dora Giannaki, "Youth work in Greece: a historical overview", in The history of youth work in Europe, Vol. 4, Marti Taru, Filip Coussée and Howard Williamson (eds), 2014, p. 91-106.

${ }^{14}$ Dimitris Foteinos, "Images of the body: the Greek physical education curriculum since the Second World War", Journal of the History of Education Society, 41(6), 2012, p. 807-822.

${ }_{15}$ Christina Koulouri, "Athleticism and antiquity: symbols and revivals in nineteenth-century Greece", The International Journal of the History of Sport, 15(3), 1998, p. 142; Patrick Comerford, "Defining Greek and Turk: Uncertainties in the search for European and Muslim identities", Cambridge Review of International Affairs, 13(2), 2000, p. 243.

${ }^{16}$ Zinon Papakonstantinou, "Epilogue: New directions in classical reception, sport and the body in Modern Greece", The International Journal of the History of Sport, 27(12), 2010, p. 2184-2186.
} 
the Ottoman authority, physical exercise represented national continuity and unity. Throughout the Armistice period, scouting activities became a hallmark of Ottoman ethnic minorities and considered as a vital part of gaining national identity. ${ }^{18}$ In this period, almost all the Muslim and non-Muslim communities in Istanbul had scouting organizations. ${ }^{19}$

The church, Rum schools and Rum press were regarded as tools of propagation in the realization of the Megali Idea by the Fener Greek Patriarchate and Greece in the Armistice period. ${ }^{20}$ The scouting activities, which had high impact on the process of propagation, can also be included among the above-mentioned propaganda tools in that period. The supports of Britain and Greece were very influential in the organization and initiation of the Rums' actions the years of the Armistice. Their support became the driving force behind the propaganda activities of Istanbul Greek Press, Fener Greek Patriarchate and scouting groups established in the schools, which was organized by the support of Greece. ${ }^{21}$ The first scouting groups of the CRSI were established at the end of 1918 and early 1919 on the basis of the following: training 'citizen-soldiers' and 'civilizing' young people. Teaching future citizens to be ready both in war and peace time, raising their morale and teaching them 'ethnic optimism' were among the roles and values of this organization. 'O Proskopos' (which means scouts) was the official publication of the CRSI. It was published and distributed in Istanbul every 15 days beginning in November 1919. The magazine, reflecting the atmosphere of time, was a guide for conveying the spirit and perceptions of the Rums. The CRSI institutionalized its troops in almost every neighborhood of Istanbul during 1919 and the 1920s. ${ }^{22}$ Additionally, Proodos Newspaper (22 January 1920) of the Ottoman Rum Community gave the details on the first anniversary of the CRSI, which was celebrated with great enthusiasm by both Greek prominent figures and Ottoman Rum community for financial and moral support to the Rum scouts. ${ }^{23}$

According to Zafer Toprak, the scouting organization in the period of Armistice Istanbul with the largest number of members was the CRSI with 2000 members in 12 groups. This organization established the basis for a platform of action in the schools, orphanages and clubs. ${ }^{24}$ As Hülya Toker explains, the scout organizations which directly belonged to Mavri Mira, a paramilitary and nationalist organization known as 'Black Fate', were aimed to stir up trouble within Ottoman Empire, to propagate Greekness and to hold public demonstrations against the Ottoman Empire. The CRSI was divided into two regiments and three separate companies. ${ }^{25}$ Rum scouts had not only organic ties with the Government of Greece, Greek scout organizations, and the Greek Red Cross but also intensely had the material and spiritual support of Rums living throughout Ottoman territory. ${ }^{26}$ This organization followed the Greek translation of Baden Powell's Boy Scout Manual and remained dedicated to nationalistic and militaristic purposes. ${ }^{27}$ Therefore, Istanbul Rum Scouting Organization was kept under

\footnotetext{
${ }^{17}$ Christina Koulouri, "From antiquity to Olympic revival: Sports and Greek national historiography (nineteenthtwentieth centuries)", The International Journal of the History of Sport, 27(12), 2010, p. 2014-2052.

${ }_{18}$ BOA (Devlet Arşivleri Başkanlığı Osmanlı Arşivi - Ottoman State Archival Document), Dahiliye Seyrüsefer Kalemi (DH.EUM.SSM.), 39/57, 15 Aralık 1919 (22/RA/1338).

${ }^{19}$ Toprak, 'Meşrutiyet ve Mütareke Yıllarında', op. cit., p. 13.

${ }^{20}$ Toker, op. cit., p. 86.

${ }^{21}$ Ibid., p. 125.

${ }^{22}$ Aslanoğlu, op. cit., p. 76-98.

${ }^{23}$ As cited in Aslanoğlu, p. 127.

${ }^{24}$ Toprak, 'Meşrutiyet ve Mütareke yıllarında' p. 22-23.

${ }^{25}$ Toker, op. cit., p., 130-131, 199.

${ }^{26}$ Aslanoğlu, op. cit., p. 97-98; BOA, Dahiliye Kalem-i Mahsus Müdüriyeti (DH.KMS.), 60/29, 13 Haziran 1921 $(06 / \mathrm{L} / 1339)$

${ }^{27}$ Toprak, “II. Meşrutiyet'ten Mütareke yıllarına", p. 24.
} 
constant supervision and exposed to various restrictions by the Ottoman authorities regarding their unwanted activities. ${ }^{28}$

Some of the Greek army officers, who were sent to Istanbul by Venizelos in order to mobilize and organize Istanbul Rums, established the Rum Müdafaa-i Milliye Cemiyeti (Rum Committee of National Defence) to protect the interests of Ottoman Rums. ${ }^{29}$ Rum scouts operating under the leadership of this association were being exposed to military education in some places where the highest percentage of Rum population lived in Istanbul particularly Bakırköy, Hasköy, and Fener. The Greek Patriarchate took an active role in the process of recruiting students and asked Rum priests to register children and young people to the scout organizations. ${ }^{30}$ In addition, Greek army officers were closely interested in the scouts and constantly supervised their activities. ${ }^{31}$ For instance, in an Ottoman tezkere ${ }^{32}$ of June 1921 stated that Greek army officers in and around Hasköy, an old neighborhood of Istanbul, oversaw the training of the scouts, continuously met with the heads of scouting groups as well as engaged in Venizelist propaganda activities. These activities were strictly followed and prosecuted by the Ottoman authorities and a detailed investigation was carried out by the Ottomans. ${ }^{33}$ According to another archive document dated 18 November 1920, it is declared that the weapons supplied by Greece to Istanbul Rum scouts were kept in the churches. ${ }^{34}$ To reach detailed knowledge about the support of the Greek army officers, the main message of an archive document can be summarized as follows:

In a Rum school in Istanbul, Rum youth regularly practiced military exercises with tubes and drums, sometimes with a musical structure shape, through the guise of scouting and these exercises were sometimes carried out even by Greek army officers dressed in civilian clothes. Furthermore, these activities were hidden under the guise of scouting activities. ${ }^{35}$

On 12 June 1919, the Ottoman Minister of War, Şevket Turgut Pasha, sent a report to the British High Command in Istanbul regarding the scouting activities of Rum community in Ottoman territory, specifically Istanbul, Thrace and Western Asia Minor. He declared that 'if the necessary military precautions were not be taken on the pretext of extraordinary situation, the responsibility of future undesirable events would not be the Ottomans'. In the same archive document, it was said that the local Rums', who wore military uniforms, established scouting groups and tightly linked to the scouting organization of Greece, were evaluated as significantly more serious because the Rum community intended to make issues against Ottoman government in the future. Şevket Turgut Pasha immediately ordered the local authorities to arrest the local Rums wearing military uniforms, to collect the weapons and ammunitions of Rums, and to abolish the scouting organizations as a solution to the problem. ${ }^{36}$ As a matter of fact, it is expressed in a report that an Armenian scout group, composed of children from Makriköy (now Bakırköy, a district of Istanbul), came for the ceremony held in

\footnotetext{
${ }^{28}$ BOA, Dahiliye Nezareti Emniyeti Umumiye Müdüriyeti Asayiş Kalemi (DH.EUM.AYŞ.), 16/84, 26 Temmuz 1919 (27/L/1337); BOA, Bab-1 Ali Evrak Odas1 (BEO), 4579/343377, 17 Haziran 1919 (18/N/1337).

${ }^{29}$ Toker, op. cit., p. 68.

${ }^{30}$ Bülent Atalay, Fener Rum Ortodoks Patrikhanesi'nin Siyasi Faaliyetleri (1908-1923), Tarih ve Tabiat Vakfi Yayınları, İstanbul 2001, p. 121-122.

31 BOA, DH.KMS., 60/29, 13 Haziran 1921 (06/L/1339); BOA, DH.EUM.AYŞ., 16/84, 26 Temmuz 1919 (27/L/1337).

${ }^{32}$ An official document issued by the Ottoman government. See Ferit Devellioğlu, Osmanlıca-Türkçe Ansiklopedik Lûgat, Ankara, 2008, pp. 1106.

${ }_{33}^{33}$ BOA, DH.KMS., 60/29, 13 Haziran 1921 (06/L/1339).

${ }^{34}$ BOA, DH.EUM.AYŞ., nr. 48/42, 1 Aralık 1920 (19/RA/1339).

${ }^{35}$ Ankara Üniversitesi Türk İnkılâp Tarihi Enstitüsü Arşivi, Kutu No: 59, Gömlek No: 115, Belge No: 115-1.

${ }^{36}$ BOA, BEO, 4579/343377, 17 Haziran 1919 (18/N/1337).
} 
the Greek Church on 14 December 1919 and afterward marched with flags in the streets. ${ }^{37}$ According to another archive report sent to the Ottoman Ministry of the Interior, it was stated that a group of twenty Rum boy scouts came to Maltepe (a district in Asian part of Istanbul) and camped there. ${ }^{38}$ These two archive documents are concrete examples of scouting activities being constantly monitored and controlled by the Ottoman government. Although security measures became stricter and Ottoman central government attempted to restrict and control detrimental actions of Rum scouting groups, the Ottoman government could not succeeded in preventing them and the Rum community largely expanded its field of influence by finding new collaboration opportunity.

Ottoman Armenians', under the influence of nationalist movement, took sides with the Rums. This was a crucial driving force for the Rums to maintain their activities during the Armistice period. ${ }^{39}$ As pointed out above, the participation of the Armenian scouting group to the ceremony, which held in Greek Church, proves that the Greeks and the Armenians occasionally acted together under the umbrella of scouting activities against the "common" opponent, the Ottoman Empire.

According to a critical report forwarded to the Ministry of the Interior from Istanbul Police Department, the Director of the Department stated that uniforms similar to the military uniforms sent from Greece for scouting organization, which was formed by the Etnik-i Eterya (the nationalist Rum organization), were distributed to the Rum youth, who were recruited to scouting organization by the Rum local authorities and priests. The report continued as follows: it is thought that six hundred uniforms were sent to Fener Greek Patriarchate and then given to the Rums yesterday and many more uniforms were expected to arrive later on. After a while, an important military force will be formed by local Rums, who are trained and embraced national feelings. Although the Rum community were seemingly free to join in the scout organization, Rum people, particularly Rum priests, worked hard to enroll Rum youth between 16 and 20 years age group in scouting organization. Not only Rum school boys and craftspeople, but also people from almost every part of Rum community were enticed to enroll in this scout organization by Rum authorities. Even, some of older scouts, 19 and 20 years old, were sent to Greece and were trained by Greek army officers in schools, churchyards, clubs, and gyms. During this critical period, a great number of Greek army officers were deployed in Istanbul to train Rum youth. In fact, the Fener Greek Patriarchate, Etnik-i Eterya Society, and the representatives of the Greek government in Ottoman territory gradually settled many Greeks in Asia Minor and Trakya (Thrace) to show that the number of Rum habitants was more than estimated. It is also known that these civilian uniformed Greek army officers had been trying to organize the scouting organization with the support and guidance of the Greek government since the occupation of Izmir (Smyrna). The Ottoman authorities should have paid more attention to this issue. ${ }^{40}$ In this case, Greece attempted to politicize the Rum youth in the direction of religious-ethnic ideologies. The Rum scouts trained impertinently under the leadership of the Greek army officers marched with Greek flags in the streets and were found engaging in behaviors such as insults and humiliation against Turks. They also promoted propaganda activities aimed at creating a chaotic environment in Istanbul. ${ }^{41}$ Being aware of these scouting actions, particularly the detrimental actions behind the camouflage of boy scout

\footnotetext{
${ }^{37}$ BOA, Dahiliye Nezareti Emniyet-i Umumiye Seyr-ü Sefer Müdüriyeti (DH.EUM.SSM.), 39/57, 15 Aralık 1919 (22/RA/1338).

${ }^{38}$ BOA, DH.EUM.AYŞ., 16/84, 26 Temmuz 1919 (27/L/1337).

${ }^{39}$ Toker, op. cit., p. 113 .

${ }^{40}$ BOA, DH.KMS., 49/34, 5 Temmuz 1919 (06/L/1337).

${ }^{41}$ As cited in Toker, op. cit., p. 50.
} 
movement, it would support the Ottomans' reaction against Rums, however, because of the travmatic effects of the Armistice years, it has not been possible. As scouting events were seen as an important platform to represent Greek national identity and national consciousness, it was not surprising that Rum population attended these events. It is clearly seen that the ultimate aim of Greek elites was to mobilize as many Rums as possible with patriotic and nationalist feelings and encouraging participation in organizations, not only in Istanbul, but throughout the Ottoman Empire.

In fact, the propaganda activities of the Rum scouting groups attracted his attention when Mustafa Kemal was the inspector of the 9th Army. He was sent a report on 22 August 1919 stating that the Rum scouting organization with members comprising of children and youngsters who are above 20 years old are totaly governed by the Mavri Mira Society and the CRSI and were greatly organized in some Ottoman cities including Istanbul, Bursa, Bandirma, Kırkkilise (Kırklareli), Tekfurdağı (Tekirdağ). Mustafa Kemal also stated that the scouting activities used to be operated by Turks; however, the activities were unfortunately abandoned even though there is a need. ${ }^{42}$ Through the scouting activities, the Greek elite and also patriarchate circles made an effort to arouse Greek national identity all over the Rum population.

In a tezkere dated 12 June 1919, written by the Ottoman General Staff to the Ottoman Ministry of Foreign Affairs, it is reported that among the members of Rum scouting organization in Istanbul there are some elderly and strong scouts, who are older than scouting age group, and these scouts constantly wear the same type of clothes. It can also be argued that this report supports concerns of Mustafa Kemal regarding the Rum scouts. ${ }^{43}$

The mutasarrlf (subgovernor) of Çatalca (a district in Thracian part of Istanbul) informs the Ottoman authorities in a report sent on 10 July 1921 shared concerns about a Rum scouting group established by a Greek citizen named Nikola. Furthermore, the mutasarrif cited not only young Rums but even also some adult Rums enrolled to this scouting group. All this information reveals that the scouting activities focused on and were embraced by all of the Rum community. Greek Captain Nikola's scouting organization was also supported by the Fener Greek Patriarchate and Rum Committee of National Defence. Although Nikola claimed 'I am an inspector of an International Scouting Organization', it was understood that the flag of this organization contained signs of the Venizelists and closely resembled the Greek flag and that in fact he was not a captain. The effort to organize this scouting organization, which aimed to revive and awaken the Greek spirit among Rum community living in the Ottoman territory, has reached an alarming dimension for the Ottoman authorities. ${ }^{44}$ In addition, the Fener Greek Patriarchate was organizing some Rum associations in order to strengthen already existing scouting organization and the tamim (circular letters) were being sent by the Patriarchate to the Orthodox churches and local Rum schools were for these purposes. ${ }^{45}$ As a result, since military ideals penetrated to the all areas of the society as social ideals, dominant militarist ideology and practices of the Armistice period prepared a legal ground for paramilitary organizations like scouting organizations.

An Ottoman archival report dating back 6 March 1921 sent from the Ministry of Interior's General Directorate of Security provides a detailed picture of Greek propaganda in Istanbul. Accordingly, Istanbul Rums came together in a Rum Boy Scout School to celebrate the election

\footnotetext{
${ }^{42}$ Ibid., p. 130.

${ }^{43}$ BOA, Hariciye Nezareti Siyasi (HR.SYS.), 2605/4, 13 Haziran 1919 (13/N/1337).

${ }^{44}$ BOA, DH.KMS., 60/47 13 Temmuz 1921 (07/ZA/1339).

${ }^{45}$ As cited in Toker, op. cit., p. 199.
} 
of Greek metropolitan (archbishop), and a Greek army officer gave an enthusiastic speech in which Venizelist propaganda was frequently acclaimed. "Venizelos will soon come into power, Ayasofya (Hagia Sophia) will be taken from the Turks, it will be got the vengeance of the slaughtered brothers in Anatolia, and the Rums should be always ready for military service.' Toward the end of his speech, the Rum community shouted 'Zito Venizelos!' (Viva Venizelos!) and his speech was vigorously applauded by the Rum attendants. Afterwards, it is further noted that the aforementioned officer personelly conducted negotiotions with Rum Committee of National Defence, which was in charge of the scouting organization. ${ }^{46}$ As stated above, documents available in the Ottoman archive also provided information on the level of Venizelist propaganda in the scouting activities. Indeed, Venizelist propaganda effectively worked to persuade Ottoman Rums to join the scouting activities and the level of these activities had reached such an extensive and organized structure that just in Istanbul there were 45 Rum scout groups under the administration of the CRSI. Furthermore, Sir Baden Powell, the founder of the Boy Scout movement, had been greatly influenced and impressed by the glorious and spectacular event of the scouts when he visited Istanbul in 1920. This spectacular event, in which 2500 Rum scouts from Istanbul and its suburbs, 150 Armenians and 40 Jewish scouts participated, inspired Baden Powell for the First World Scout Jamboree (the International Scouts Meeting), which was held in London from 30 July to 8 August 1920 with the participation of 8000 scouts from 34 countries including Greece. ${ }^{47}$ These events can be interpreted that the international community supported the Rum community. Meanwhile, the relationship and solidarity of the Rums with the international community was not limited to this event. In 1920, the head of the CRSI had applied to its American counterpart for financial aid resulted in a generous amount of money. ${ }^{48}$

The Rum community was quite active in the expansion of propaganda activities of Greece towards all the public spheres. During the Armistice period, the Rum schools in Istanbul had become one of the most important trivets where scouting activities continued as an important contributor of promoting the Greek ideology. The Rum schools managed by the Fener Greek Patriarchate also served as the scouting camps where the armed military trainings were held and Greek army officers served as teachers throughout this period. ${ }^{49}$ Istanbul Directorate of Education attracted attention to the seriousness of the situation by saying the vast majority of the Rum schools established scouting organizations and that some scouting activities were being conducted during these days. ${ }^{50}$ As stated previously, the meeting was held in a Rum school because of the Greek Metropolitan elections. ${ }^{51}$ The use of a Rum school for metropolitan elections does not directly reflect the close relationship between the Boy Scout movement and political activities. This means that the young Rum population was constantly kept under the influence of propaganda activities through scouting organizations both inside and outside of the Rum schools and in all the areas of public life.

The education in Rum scouting organization given by Greek army officers, local parishes, and the officials of Greek Embassy to young Rums aged 15 years or older was implemented in places that would not attract much attention such as schools, churches, Rum clubs and

\footnotetext{
${ }^{46}$ BOA, HR.SYS., 2605/5, 7 Mart 1921 (26/C/1339).

47 As cited in Aslanoğlu, op. cit., p. 122-123, 144; [History of the World Scout Jamboree] $<$ https://www.scout.org/sites/default/files/library_files/amboree\%20History\%20.pdf >, (Last accessed on 27 August 2018); [The Jamboree book, 1920: 1st World Jamboree, Olympia, England] <https://www.pinetreeweb.com/1920wj1-tjb-00.html>, (Last accessed on 27 August 2018).

${ }^{48}$ As cited in Aslanoğlu, op. cit., p. 99.

${ }^{49}$ Toker, op. cit., p. 80-83.

${ }^{50}$ BOA, DH.KMS., 49/34, 5 Temmuz 1919 (06/L/1337).

${ }^{51}$ BOA, HR.SYS., 2605/5, 7 Mart 1921 (26/C/1339).
} 
gymnastics associations. ${ }^{52}$ The Rum scouts encouraged a sense of nationalist and militarist duty. As well, over the years, besides their physical activities, there also existed some armed confrontations against the Turks and local police officers. In other words, the mass political struggles of Rum scouts sometimes were accompanied with armed and violent actions. For instance, in the case that happened around the Galata police station, a Muslim was attacked and killed by almost fifty Rum scouts using sticks. The scouts then attacked the Galata police station and shot at soldiers who interfered with these events. ${ }^{53}$

Meanwhile, the encouraging developments of the scouting activities led to the strengthening of other scouting organizations in various parts of the Ottoman Empire, particularly in Aegean region including Izmir and Aydın. There was a quite strong scouting organization in Izmir with 2331 members. ${ }^{54}$ According to an archive document dated to 30 June 1919 sent to Ottoman Ministry of Interior, there were some scouting groups, which were under the protection of the Greek government, founded before the occupation of İzmir. This report warned the Ottoman authorities that necessary precautions should be taken to avoid the further spread of these groups. ${ }^{55}$

As the occupation of Izmir and Aydin approached, collaboration between the Greek government, Greek army and the Rum scouts regarding the scouting activities intensified. When the Greek army occupied İzmir and Aydın in May 1919, the Rum scouts were already organized. In 1920, during the Armistice period, the number of Rum Boy Scouts expanded exponentially and there were 33 Boy Scout troops with 1,500 scouts, who carried on their activities in this region. The Rum lobby had enlarged areas of activity and were actively involved in scouting activities before the occupation of Izmir. During the occupation days of the Greek army, the Rum scouts also joined armed struggles in the front line of the Greek Army, which occurred between the Turkish and Greek troops in Aydin Province. Twenty Rum scouts were killed by Turkish forces. ${ }^{56}$ At this time, the military rivalry between Greece and the Ottoman Empire made boy scout movement one of the major determinants in the balance of power and also made a crucial propaganda tool. Thus one may concluded that the militarist actions of Rum scouts directly reached a critical level due to warlike conditions, going far beyond the aim of physical activity.

Additionally, scouting activities of local Rums were kept under constant supervision and guidance by the Ottoman authorities in other regions of the Ottoman Empire. For instance, in Finike, a district in eastern Mediterranean region of Asia Minor, it was reported that a gang and scouting organization had attempted to establish with the participation of local Rums. However, as a result of a detailed investigation of kaymakam (district governer) in Finike, it was understood that this claim was misleading and totally groundless. ${ }^{57}$ Under the conditions of massive expansion of Rum Boy Scout movement, the Ottoman government was also evaluated the intelligences coming from various Ottoman ministries in determining the measures to be taken against the Rums. The intelligence examples collected from ministries contained the following information: the structure of the scout organizations established in the schools, who

\footnotetext{
${ }^{52}$ Toker, op. cit., p. 136.

${ }^{53}$ Ibid., p. 45-46.

54 Engin Berber, Sancılı Yıllar: İzmir 1918-1922, Mütareke ve Yunan işgali döneminde İzmir Sancă̆l, Ayraç Yayınevi, İstanbul 1997, p. 339-340.

${ }_{55}$ BOA, DH.KMS., 49/34, 5 Temmuz 1919 (06/L/1337).

${ }_{57}^{56}$ As cited in Aslanoğlu, op. cit., p. 76-79.

${ }^{57}$ BOA, DH.KMS., 49-47, 28 Temmuz 1919 (09/ZA/1337); BOA, Dahiliye Şifre Kalemi (DH.ŞFR.), 637/99, 15 Eylül 1919 (R. 15/07/1335).
} 
managed these organizations, who benefitted from these organizations and how many Rums are being trained in these organizations. ${ }^{58}$

In spite of the decisions regarding abolishment of Rum scouting organizations and also the ban of scouting activities by Ottoman administrators, which had military or semi-military structure, they rigorously maintained their activities. In other words, Ottoman government's attempt to prevent the detrimental actions of Rum scouts was not enough and they needed to apply more radical control measures and policies.

\section{Conclusion}

Considering the socio-political atmosphere in the first quarter of the twentiethth century, the creation of a nationalist youth model in harmony with the nation-state model was an important issue. It is known that the indispensable values of the nationalist ideology, mainly discipline, hierarchy, strength and militancy, shape the daily life of the youth in a great way. Additionally, the evolution of Power Politics into a militarized structure in the context of the nation-state model was continuously accompanied by keeping alive the war atmosphere. The nationalism, as a driving force and main motivation source behind the scouting activities during the Armistice period, has represented the role and influence of physical activity and Boy Scout movement in the formation of Greek national identity, especially in the case of Rum scouting movement. In particular, the Rum scouting groups in Istanbul, Trakya and Asia Minor had endeavored to improve and strengthen the ideology of 'Megali Idea' with a national energy motivation. In this context, the Rum Boy Scout movement was regarded as more and more necessary for overall Greek nation's strength and military preparation; and constructing strong and robust body was percieved as a crucial element in mobilizing the masses.

Mavri Mira Society, Etnik-i Eterya Society and Rum Committee of National Defence, all flourished during the chaotic war years and were organized among local Rums in order to promote Greek national identity and to create Greater Greece. These organizations provided Greek elite with instruments for extending its political influence on local Rums, who then attempted to mobilize the ethnic-formation of the local Rums by means of the remarkable material and spiritual support of the Greek government. In this process, they were also connected with the Fener Greek Patriarchate, which had the largest organizational structure among the Rums. Furthermore, the Greece government, as a determiner of policymaking of Rums, not only supported the establishment operations of the scouting organizations, but also settled many Greece army officers in Istanbul and Asia Minor. Gradually and, especially, during the Armistice period, the Rum scouting groups acquired a more active role, putting forward important initiatives.

When we look at the structure and transformation of Rum Boy Scout movement, it is clearly seen that the identity of Rums is constituted by state supported structures. In this context, the design of Greek identity among local Rums had moved beyond just being theoretical and put into practice. It had successfully attempted to reach the target group, particularly the local Rum youth.

The CRSI became quite popular among local Rum community, who absorbed and adopted many elements and practices of Greek nationalism and Venizelist ideology. Despite the fact that the organization was just newly formed, this organization gathered together Rum community under the umbrella of 'common interest'. The Ottoman Rum community adopted Venizelism as a national dream as this policy was strongly related with the economic, political

\footnotetext{
${ }^{58}$ Toker, op. cit., p. 183.
} 
and social circumstances of the period, and they also believed that this would have a positive impact on the nation building process. The Rum scouting movement reached the peak of its presence during the Greco-Turkish War (1919-1922) and was easily integrated in the war mobilization process with the contribution of popular Venizelist enthusiasm. Briefly, it has been argued that the Armistice period created a political milieu for the spreading of Rum propaganda activities owing to the Ottoman's lack of authority and influence. The Rum community living in the Ottoman territory produced strong tension through scouting organizations against the Ottoman authority. In conclusion, following the defeat of Greece in the 1919-1922 war, the Megali Idea ended with a national disaster for Greece and Rums community leading to a real national crisis and collective trauma and the CRSI completely disappeared from Istanbul and Asia Minor. ${ }^{59}$

\section{Bibliography}

A. Devlet Arşivleri Başkanlığ 1 Osmanlı Arşivi

Bab-ı Ali, Evrak Odası

Dahiliye Nezareti, Emniyeti Umumiye Müdüriyeti Asayiş Kalemi

Dahiliye Nezareti, Emniyet-i Umumiye Seyr-ü Sefer Müdüriyeti

Dahiliye Nezareti, Kalem-i Mahsus Müdüriyeti

Dahiliye Nezareti, Seyrüsefer Kalemi

Dahiliye Nezareti, Şifre Kalemi

Hariciye Nezareti, Siyasi

Ankara Üniversitesi Türk İnkılâp Tarihi Enstitüsü Arşivi, Kutu No: 59, Gömlek No: 115, Belge No: 115-1.

ASLANOĞLU, Anna Maria, Staying away from politics, not foreseeing militarism: The case of Corps of Greek Scouts in Armistice Istanbul, 1918-1923, (Boğaziçi University, Unpublished master's thesis), Istanbul, 2010.

ATALAY, Bülent, Fener Rum Ortodoks Patrikhanesi'nin Siyasi Faaliyetleri (1908-1923), Tarih ve Tabiat Vakfı Yayınları, İstanbul 2001.

BERBER, Engin, Sancll Yıllar: İzmir 1918-1922, Mütareke ve Yunan işgali döneminde İzmir Sancă̆l, Ayraç Yayınevi, İstanbul 1997.

COMERFORD, Patrick, "Defining Greek and Turk: Uncertainties in the search for European and Muslim identities", Cambridge Review of International Affairs, 13(2), 2000, p. 240-253.

DEVELLIOĞLU, Ferit, Osmanlıca-Türkçe Ansiklopedik Lûgat, Aydın Kitabevi Yayınları, Ankara 2008.

FOTEINOS, Dimitris, "Images of the body: the Greek physical education curriculum since the Second World War", Journal of the History of Education Society, 41(6), 2012, p. 807-822.

GEORGEON, François - Paul DUMONT, (eds), Osmanlı Imparatorluğu'nda Yaşamak, İletişim Yayınları, İstanbul 2000.

${ }^{59}$ Aslanoğlu, op. cit., p. 64-65. 
GIANNAKI, Dora, "Youth work in Greece: a historical overview", in The history of youth work in Europe, Vol. 4, Marti Taru, Filip Coussée and Howard Williamson (eds), 2014, p. 91-106.

KOULOURI, Christina, "Athleticism and antiquity: symbols and revivals in nineteenth-century Greece", The International Journal of the History of Sport, 15(3), 1998, p. 142-149.

KOULOURI, Christina, "From antiquity to Olympic revival: Sports and Greek national historiography (nineteenth-twentieth centuries)", The International Journal of the History of Sport, 27(12), 2010, p. 2014-2052.

MADSUKYAN, Nazan, "Agents or Pawns? Nationalism and Ottoman children during the Great War", Journal of the Ottoman and Turkish Studies Association, 3(1), 2016, p. 139-164.

PAPAKONSTANTINOU, Zinon, "Epilogue: New directions in classical reception, sport and the body in Modern Greece", The International Journal of the History of Sport, 27(12), 2010, pp. 2184-2186.

TOKER, Hülya, Mütareke Döneminde Istanbul Rumları, Genelkurmay ATESE ve Denetleme Başkanlığı Yayınları, Ankara 2006.

TOPRAK, Zafer, 'II. Meşrutiyet Dönemi'nde paramiliter gençlik örgütleri', in Tanzimat'tan Cumhuriyet'e Türkiye Ansiklopedisi, Vol. 2, 1985, p. 531-536.

TOPRAK, Zafer "Meşrutiyet ve mütareke yıllarında Türkiye'de izcilik", Toplumsal Tarih, 52, April 1998, p. 13-20.

TOPRAK, Zafer, “II. Meşrutiyet'ten Mütareke yıllarına: Türkiye'de izciliğin ilk evresi”, Tombak, 24, February 1999, p. 19-27.

[History of the World Scout Jamboree] $<$ https://www.scout.org/sites/default/files/library_files/amboree\%20History\%20.pdf >, (Last accessed on 27 August 2018)

[The Jamboree book, 1920: 1st World Jamboree, Olympia, England] $<$ https://www.pinetreeweb.com/1920-wj1-tjb-00.html>, (Last accessed on 27 August 2018). 